\title{
Pengaruh Perilaku Konsumen terhadap Pengambilan Keputusan dalam Menentukan Destinasi Wisata di Kabupaten Hulu Sungai Tengah
}

\author{
Gusti Marliani ${ }^{1}$, Toto Sugiarto ${ }^{2}$, \\ ${ }^{12}$ Fakultas Ekonomi Universitas Achmad Yani Banjarmasin \\ Email : gustimarliani@uay.ac.id
}

\begin{abstract}
The purpose of this study is to analyze the influence of consumer behavior on their decision making both partially and simultaneously in determining the Tourism Destination to Hulu Sungai Tengah District. The results of this study can provide input for stakeholders in decision making to advance tourism in Hulu Sungai Tengah, in this case, can help increase the number of tourist visits in Hulu Sungai Tengah.. Simultaneously / thoroughly independent variables which include Cultural Factor Variables (X1), Social Factor Variables (X2), Personal Factor Variables (X3), and Psychological Factor Variables (X4) simultaneously have a significant effect on consumer decision making in determining Tourism Visits $(Y)$ in Hulu Sungai Tengah Regency. The test results show that $F$ count is greater than $F$ table $(F$ count $=267,457>F$ table $=3.81)$. Adjusted $R$ Square equal to 0.965 , which means that the independent variable has a contribution variance of $96.5 \%$ to the dependent variable, while the remaining $3.5 \%$ is given by other variables not included in this study.
\end{abstract}

Keywords : Consumer Behavior, Consumer Decisions, Tourist Destinations

Abstrak

Tujuan penelitian ini untuk menganalisis pengaruh perilaku konsumen terhadap pengambilan keputusan mereka baik secara parsial maupun secara simultan dalam menentukan Tujuan Wisata Ke Kabupaten Hulu Sungai Tengah. Hasil penelitian ini dapat memberikan masukan bagi pengampu kepentingan dalam pengambilan keputusan untuk memajukan wisata di Hulu Sungai Tengah, dalam hal ini dapat membantu meningkatkan jumlah kunjungan wisata di Hulu Sungai Tengah. Secara simultan/ menyeluruh variabel independen yang meliputi Variabel Faktor Kebudayaan $\left(\mathrm{X}_{1}\right)$, Variabel Faktor Sosial $\left(\mathrm{X}_{2}\right)$, Variabel Faktor Pribadi $\left(\mathrm{X}_{3}\right)$, dan Variabel Faktor Psikologis $\left(\mathrm{X}_{4}\right)$ secara simultan berpengaruh signifikan terhadap pengambilan keputusan konsumen dalam menentukan Kunjungan Wisata (Y) di Kabupaten Hulu Sungai Tengah. Hasil uji bahwa ternyata $\mathrm{F}$ hitung lebih besar dari $\mathrm{F}$ tabel $(\mathrm{F}$ hitung $=267.457>\mathrm{F}$ tabel $=3,81)$. Koefisien determinasi disesuaikan (Adjusted R Square) sebesar 0,965 yang berarti bahwa variabel independen mempunyai variansi kontribusi sebesar 96,5\% terhadap variabel dependen, sedangkan sisanya adalah 3,5\% diberikan oleh variabelvariabel lain yang tidak termasuk dalam penelitian ini.

Kata Kunci : Perilaku Konsumen, Keputusan Konsumen, Tujuan Wisata

(C) 2019 Jurnal Riset Inspirasi Manajemen dan Kewirausahaan

\section{PENDAHULUAN}

Indonesia memiliki kekayaan dan sumber daya alam yang melimpah serta didukung dengan lautan dan ribuan pulau yang mengelilinginya. Berbagai kekayaan sumber daya alam yang dimilikinya menjadi potensi tersendiri bagi Indonesia untuk mengembangkan pariwisata terutama dibidang alamnya. Indonesia sebagai negara kepulauan terbesar di dunia yang terdiri dari 17.508 pulau atau disebut juga sebagai nusantara atau negara maritim, telah menyadari pentingnya sektor pariwisata terhadap perekonomian Indonesia dikarenakan pertumbuhan pariwisata Indonesia selalu di atas pertumbuhan ekonomi Indonesia. Maka dari itu pariwisata belakangan ini selalu menjadi pusat perhatian bagi wisatawan untuk mengunjungi tempat wisata tersebut. (Soebagyo, 2012).

Sektor pariwisata merupakan sektor yang potensial untuk dikembangkan sebagai salah satu sumber pendapatan daerah. Usaha memperbesar pendapatan asli daerah, maka program pengembangan dan pendayagunaan sumber daya dan potensi pariwisata daerah diharapkan dapat memberikan sumbangan bagi pembangunan ekonomi. Secara luas pariwisata dipandang sebagai kegiatan yang mempunyai multidimensi dari rangkaian suatu proses pembangunan. Pembangunan sektor pariwisata menyangkut aspek sosial budaya, ekonomi dan politik (Spillane, 2004: 14). 
Tabel

Jumlah Obyek Wisata di Kabupaten Hulu Sungai Tengah

\begin{tabular}{|c|c|c|}
\hline No & $\begin{array}{l}\text { Nama Obyek } \\
\text { Wisata }\end{array}$ & $\begin{array}{l}\text { Lokasi Obyek } \\
\text { Wisata }\end{array}$ \\
\hline 1. & $\begin{array}{l}\text { Wisata taman batu } \\
\text { benawa }\end{array}$ & Kec. Batu Benawa \\
\hline 2. & $\begin{array}{l}\text { Wisata alam Sungai } \\
\text { Muui /Lok Laga Ria }\end{array}$ & Kec. Haruyan \\
\hline 3. & $\begin{array}{l}\text { Wisata alam sumber } \\
\text { air panas }\end{array}$ & Kec. Hantakan \\
\hline 4. & $\begin{array}{lr}\text { Wisata } & \text { alam } \\
\text { bendungan } & \text { sakutang } \\
\text { indah } & \\
\end{array}$ & $\begin{array}{l}\text { Kec. Batang Alai } \\
\text { Timur }\end{array}$ \\
\hline 5. & $\begin{array}{l}\text { Wisata alam gunung } \\
\text { saguling (meratus) }\end{array}$ & $\begin{array}{l}\text { Kec. Batang Alai } \\
\text { Selatan, Kec. } \\
\text { Batang Alai Timur, } \\
\text { Kec. Batu Benawa, } \\
\text { dan Kec. Hantakan }\end{array}$ \\
\hline 6. & $\begin{array}{l}\text { Wisata alam gunung } \\
\text { halau-halau } \\
\text { (meratus) }\end{array}$ & $\begin{array}{l}\text { Kec. Batang Alai } \\
\text { Selatan, Kec. } \\
\text { Batang Alai Timur, } \\
\text { Kec. Batu Benawa } \\
\text { dan Hantakan }\end{array}$ \\
\hline 7. & $\begin{array}{l}\text { Wisata alam gunung } \\
\text { janjar pitu }\end{array}$ & $\begin{array}{l}\text { Kec. Batang Alai } \\
\text { Timur }\end{array}$ \\
\hline 8. & $\begin{array}{l}\text { Wisata alam air } \\
\text { terjun }\end{array}$ & Kec. Hantakan \\
\hline 9. & Wisata rawa & $\begin{array}{l}\text { Kec. Labuan Amas } \\
\text { Utara }\end{array}$ \\
\hline
\end{tabular}

Sumber: Disbudparpora Kabupaten Hulu Sungai Tengah, 2017.

Perdagangan merupakan kegiatan yang terpadu untuk mengembangkan rencana-rencana strategis yang diarahkan pada usaha pemuasan kebutuhan dan keinginan pembeli, guna mendapatkan penjualan yang menghasilkan laba. Penjualan merupakan sumber hidup suatu usaha perdagangan, karena dari penjualan dapat memperoleh laba serta suatu usaha memikat konsumen yang diusahakan untuk mengetahui daya tarik mereka sehingga dapat mengetahui hasil suatu produk yang dihasilkan.

Cukup banyaknya tempat tujuan wisata yang tersedia Kabupaten Hulu Sungai Tengah tentunya berpengaruh terhadap pendapatan daerah, selain berbagai faktor lainnya yang mempengaruhi pendapatan daerah, tempat wisata juga mempunyai kontribusi bagi peningkatan pendapatan pedagang yang ada di sekitar tempat wisata. Dengan banyaknya tempat tujuan wisata yang terdapat di kabupaten Hulu Sungai Tengah menyebabkan pengunjung wisata mempunyi banyak pilihan dalam pengambilan keputusan untuk menentukan tujuan wisata.

Pariwisata menurut Yoeti (1996) dalam Sidarta (2002) merupakan suatu perjalanan yang dilakukan untuk sementara waktu, diselenggarakan dari suatu tempat ke tempat lain, dengan maksud bukan untuk mencari nafkah di tempat yang dikunjungi, melainkan untuk menikmati perjalanan tersebut guna memenuhi keinginan yang beranekaragam. Kegiatan pariwisata yang dikelola dengan baik dapat menghasilkan manfaat ekonomi yang berarti dengan pemanfaatan yang berdampak kecil terhadap kawasan lindung. Kegiatan pariwisata pada daerah yang dilindungi, bila diatur dan dikendalikan secara baik akan mengarah pada pemanfaatan ekonomi dengan dampak kerusakan yang minimum.

Seorang konsumen tentu memiliki kebutuhan yang tidak terbatas tetapi alat pemuas kebutuhannya sangat terbatas. Tentu saja semua kebutuhan tersebut tidak mungkin mampu dipenuhi semuanya karena kita memiliki keterbatasan. Kita tentu tidak memiliki uang yang cukup untuk membeli semua barang yang kita butuhkan tersebut. Hal inilah yang menjadikan perlunya kita mempelajari perilaku konsumen dalam memenuhi kebutuhannya.

Setiap konsumen berusaha mengalokasikan penghasilan yang terbatas jumlahnya untuk membeli barang dan jasa yang tersedia di pasar sedemikian rupa sehingga tingkat kepuasan yang diperolehnya maksimum. Demikian pula seorang produsen mengorganisir produksi yang selanjutnya menentukan penawaran barang di pasar. Perubahan perilaku konsumen dalam menganalisis hingga memutuskan untuk membeli atau menggunakan suatu produk yang ditawarkan merupakan salah satu faktor yang tidak dapat dikendalikan oleh pihak pemasar. Oleh sebab itu perlu adanya analisa terhadap perilaku konsumen oleh pihak pemasar.

\section{KAJIAN LITERATUR}

Teori perilaku konsumen adalah deskripsi tentang bagaimana konsumen mengalokasikan pendapatan antara barang dan jasa yang berbedabeda untuk memaksimalkan kesejahteraan mereka. Kemudian pemahaman-pemahaman tentang keputusan pembelian konsumen akan membantu kita memahami bagaimana perubahan pendapatan dan harga memengaruhi permintaan untuk barang dan jasa serta mengapa permintaan untuk beberapa produk lebih sensitive dari pada produk lainnya pada perubahan harga dan pendapatan (Sarnowo dan Sunyoto, 2011:71).

Menurut Robert Pindyck dalam Dadang Sunyoto dan Henry Sarnowo (2011:71-72) cara terbaik untuk memahami prilaku konsumen adalah dengan tiga langkah yang berbeda, yaitu:

1. Preferensi konsumen

Langkah pertama adalah menemukan cara praktis untuk menggambarkan alasan-alasan 
mengapa orang lain lebih suka satu barang dari pada barang yang lain.

2. Keterbatasan anggaran

Sudah pasti konsumen juga mempertimbangkan harga. Oleh karena itu dalam langkah kedua ini kita harus menyadari adanya kenyataan bahwa konsumen mempunyai keterbatasan pendapatan yang membatasi jumlah barang yang dapat mereka beli.

3. Pilihan-pilihan konsumen

Dengan mengetahui preferensi dan keterbatasan pendapatan mereka, konsumen memilih untuk membeli kombinasi barangbarang yang memaksimalkan kepuasaan mereka. Kombinasi ini akan bergantung pada harga berbagai barang tersebut. Jadi, pemahaman pada pilihan konsumen akan membantu kita memahami permintaan, yaitu berapa banyak jumlah suatu barang yang dipilih konsumen untuk dibeli bergantung pada harganya.

Perilaku konsumen menyangkut masalah keputusan yang diambil seseorang dalam persaingannya dan penentuan untuk mendapatkan dan mempergunakan barang dan jasa. Konsumen mengambil banyak macam keputusan membeli setiap hari. Kebanyakan perusahaan besar meneliti keputusan membeli konsumen secara amat rinci untuk menjawab pertanyaan mengenai apa yang dibeli konsumen, dimana mereka membeli, bagaimana dan berapa banyak mereka membeli, serta mengapa mereka membeli. Pemasar dapat mempelajari apa yang dibeli konsumen untuk mencari jawaban atas pertanyaan mengenai apa yang mereka beli, dimana dan berapa banyak, tetapi mempelajari mengenai alasan tingkah laku konsumen bukan hal yang mudah, jawabannya seringkali tersembunyi jauh dalam benak konsumen.

Swastha dan Handoko (2007:10) mengatakan perilaku konsumen (consumer behavior) dapat didefinisikan sebagai kegiatan-kegiatan individu yang secara langsung terlibat dalam mendapatkan dan mempergunakan barang-barang dan jasa-jasa, termasuk didalamnya proses pengambilan keputusan pada persiapan dan menentukan kegiatan-kegiatan tertentu.

Dari pengertian di atas maka perilaku konsumen merupakan tindakan-tindakan dan hubungan sosial yang dilakukan oleh konsumen perorangan, kelompok maupun organisasi untuk menilai, memperoleh dan menggunakan barangbarang serta jasa melalui proses pertukaran atau pembelian yang diawali dengan proses pengambilan keputusan yang menentukan tindakantindakan tersebut.

Menurut Kotler (2010:144) faktor-faktor yang mempengaruhi perilaku konsumen adalah kebudayaan, faktor sosial, pribadi, psikologis. Sebagian faktor-faktor tersebut tidak diperhatikan oleh pemasar tetapi sebenarnya harus diperhitungkan untuk mengetahui seberapa jauh faktor-faktor perilaku konsumen tersebut mempengaruhi pembelian konsumen.

Gambar

Faktor-faktor yang Mempengaruhi Tingkah Laku Konsumen

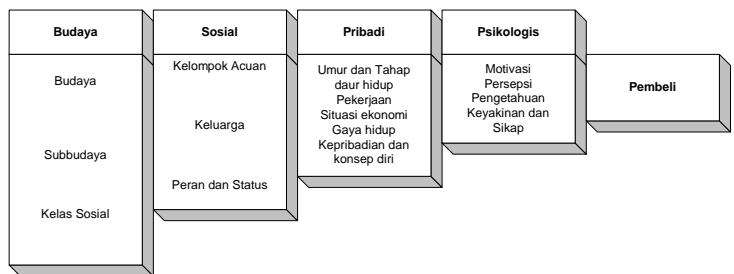

Sumber : (Kotler, 2010:144)

Menurut Engel et. Al (2008:31) Keputusan pembelian adalah proses merumuskan berbagai alternatif tindakan guna menjatuhkan pilihan pada salah satu alternatif tertentu untuk melakukan pembelian.

Pemasar perlu mengetahui siapa yang terlibat dalam keputusan membeli dan peran apa yang dimainkan oleh setiap orang untuk banyak produk, cukup mudah untuk mengenali siapa yang mengambil keputusan.

Menurut Engel et. Al (2008:33) beberapa peran dalam keputusan membeli:

a. Pemrakarsa orang yang pertama menyarankan atau mencetuskan gagasan membeli produk atau jasa tertentu.

b. Pemberi pengaruh: orang yang pandangan atau sarannya mempengaruhi keputusan membeli.

c. Pengambil keputusan : orang yang akhirnya membuat keputusan membeli atau sebagian dari itu, apakah akan membeli, apa yang dibeli, bagaimana membelinya atau di mana membeli.

d. Pembeli : orang yang benar-benar melakukan pembelian

e. Pengguna : orang yang mengkonsumsi atau menggunakan produk atau jasa.

Mengetahui peserta utama proses pembelian dan peran yang mereka mainkan membantu pemasar untuk menyesuaikan program pemasaran.

Semakin kompleks keputusan yang harus diambil biasanya semakin banyak pertimbangannya untuk membeli. Menurut (Kotler, 2010:160) adapun jenis-jenis tingkah laku membeli konsumen berdasarkan pada derajat keterlibatan dan tingkat perbedaan antara merek, yaitu:

a. tingkah laku membeli yang komplek

b. tingkah laku membeli yang mengurangi ketidakcocokan.

c. tingkah laku membeli yang mencari variasi 
d. tingkah laku membeli yang menjadi kebiasaan.

Menurut (Kotler, 2010:204) tahap-tahap yang dilewati pembeli untuk mencapai keputusan membeli melewati lima tahap, yaitu:
a. Pengenalan Masalah
b. Pencarian Informasi
c. Evaluasi alternatif
d. Keputusan Membeli

\section{METODE PENELITIAN}

Penelitian ini dilakukan di lokasi objek wisata yang terdapat di Kabupten Hulu Sungai Tengah tahun 2018. Dengan variabel penelitian Perilaku Konsumen yang meliputi faktor kebudayaan $\left(\mathrm{X}_{1}\right)$, faktor sosial $\left(\mathrm{X}_{2}\right)$, faktor pribadi $\left(\mathrm{X}_{3}\right)$ faktor psikologis $\left(\mathrm{X}_{4}\right)$ terhadap pengambilan keputusan untuk melakukan kunjungan wisata di Kabupaten Hulu Sungai Tengah, maka ada dua buah variabel yang akan dianalisis dalam penelitian ini. Kedua variabel tersebut adalah:

Variabel terikat (dependent variable) yang disimbolkan dengan (Y) adalah pengambilan keputusan konsumen dalam melakukan kunjungan wisata.

Variabel bebas (independet variable) yang disimbolkan dengan (X) adalah perilaku konsumen dengan indikator variabel meliputi: faktor kebudayaan $\left(\mathrm{X}_{1}\right)$, faktor sosial $\left(\mathrm{X}_{2}\right)$, faktor pribadi $\left(\mathrm{X}_{3}\right)$ faktor psikologis $\left(\mathrm{X}_{4}\right)$.

1. Faktor kebudayaan $\left(\mathrm{X}_{1}\right)$

Kebudayaan merupakan penentu keinginan dan perilaku yang paling mendasar untuk mendapatkan nilai, persepsi, preferensi dan perilaku dari lembaga-lembaga penting lainnya

2. Faktor sosial $\left(\mathrm{X}_{2}\right)$

Kelas sosial merupakan Pembagian masyarakat yang relatif homogen dan permanen yang tersusun secara hierarkis dan yang anggotanya menganut nilai-nilai, minat, dan perilaku yang serupa.

3. Faktor pribadi $\left(\mathrm{X}_{3}\right)$

Faktor pribadi didefinisikan sebagai karakteristik psikologis seseorang yang berbeda dengan orang lain yang menyebabkan tanggapan yang relatif konsisten dan bertahan lama terhadap lingkungan.

4. Faktor psikologis $\left(\mathrm{X}_{4}\right)$

Faktor psikologis sebagai bagian dari pengaruh lingkungan dimana ia tinggal dan hidup pada waktu sekarang tanpa mengabaikan pengaruh dimasa lampau atau antisipasinya pada waktu yang akan datang.

Pengambilan sampling secara sistematik digunakan karena peneliti dihadapkan pada ukuran populasi yang banyak dan tidak memiliki alat pengambil data secara random (Sugiyono, 2002).
Pengambilan sampel dilakukan selama 10 hari berurutan, yaitu dari hari senin sampai 10 hari ke depan. Dalam hal ini peneliti membagikan kuesioner/ angket kepada responden sebanyak 4 orang per harinya dengan catatan waktu setiap setengah jam sekali dari tiap akhir pengisian angket responden, sehingga total responden yang diambil adalah 40 orang responden. Pengambilan responden selama 10 hari ini dirasa cukup untuk memenuhi kebutuhan data yang diperlukan untuk mengetahui perilaku konsumen dalam hal pengambilan keputusan (Sugiyono, 2002:89).

Untuk menentukan ada tidaknya pengaruh dari variabel independen (X) terhadap variabel dependent (Y) digunakan model analisis regresi linier/ regresi berganda (multiple linier regression) dengan model persamaan:

$$
Y=a+\beta_{1} X_{1}+\beta_{2} X_{2}+\beta_{3} X_{3}+\beta_{4} X_{4}+e i
$$

(Hasan Iqbal, 2008:47)

Dimana :

$$
\begin{aligned}
& \mathrm{Y} \quad=\text { Pengambilan Keputusan } \\
& \text { a } \quad=\text { Konstanta } \\
& \beta=\text { Koefisien regresi } \\
& \mathrm{X}_{1} \quad=\text { Faktor kebudayaan } \\
& \mathrm{X}_{2} \quad=\text { Faktor sosial } \\
& \mathrm{X}_{3} \quad=\text { Faktor pribadi } \\
& \mathrm{X}_{4} \quad=\text { Faktor psikologis } \\
& \text { ei }=\text { Kesalahan pengganggu, berupa variabel }
\end{aligned}
$$

\begin{tabular}{|c|c|c|c|c|c|}
\hline $\begin{array}{c}\text { Variabel } \\
\text { Terikat }\end{array}$ & $\begin{array}{c}\text { Variabel } \\
\text { Bebas }\end{array}$ & $\begin{array}{c}\text { Koefisien } \\
\text { Regresi }\end{array}$ & Se $\beta$ & $\mathrm{T}_{\text {hitung }}$ & VIP \\
\hline \multirow{4}{*}{$\begin{array}{l}\text { Pengambilan } \\
\text { Keputusan } \\
\text { (Y) }\end{array}$} & Kebudayaan $\mathrm{X}_{1}$ & .175 & .137 & 1.383 & 1.009 \\
\hline & Sosial $X_{2}$ & .112 & .095 & 1.633 & 1.007 \\
\hline & Pribadi $X_{3}$ & .002 & .315 & 3.324 & 1.005 \\
\hline & Psikologis $\mathrm{X}_{4}$ & .000 & .475 & 5.428 & 1.002 \\
\hline \multicolumn{2}{|l|}{ Constanta } & \multicolumn{4}{|l|}{$: 0,072$} \\
\hline \multicolumn{2}{|c|}{ Koefisien Determinasi } & \multicolumn{4}{|c|}{$: \mathrm{R}=.984^{\mathrm{a}}=.968$} \\
\hline \multicolumn{2}{|c|}{$\mathrm{F}_{\text {hitung }}$} & \multicolumn{4}{|c|}{$:$ Adjusted $\mathrm{R}^{2}=.965$} \\
\hline \multicolumn{2}{|l|}{ Sig.F } & \multicolumn{4}{|c|}{$: 267.457$} \\
\hline \multicolumn{2}{|c|}{$\mathrm{F}_{\text {tabel }} 5 \%$ pada $\mathrm{n}-\mathrm{k}-1=(40-4-1)$} & \multicolumn{4}{|l|}{$: 0,000$} \\
\hline \multicolumn{2}{|c|}{$\mathrm{t}_{\text {tabel }} 5 \%$ pada df $(40-4)$} & \multicolumn{4}{|l|}{$: 3,81$} \\
\hline
\end{tabular}

\section{HASIL PENELITIAN DAN PEMBAHASAN}

Hasil penelitian setelah melewati uji validitas dan reliabilitas dari data masing-masing faktor yang telah valid dan reliabel kemudian diolah dengan menggunakan program SPSS versi 16.0 for windows dan diperoleh hasil estimasi regresi sebagai berikut:

Tabel

Hasil Estimasi Regresi Berganda

Sumber : Print Out Hasil Estimasi Regresi Multiple Regression 
Berdasarkan pengolahan dan analisis data dengan mempergunakan Program SPSS versi 16.0 for windows dapatlah diketahui persamaan regresinya dengan melihat Coefisient pada Unstandarized coefisients bagian B sebagai berikut:

$$
\begin{aligned}
& Y=0,072+0,175 X_{1}+0,112 X_{2}+0,002 X_{3}+0,000 \\
& X_{4}+e i
\end{aligned}
$$

Multikolinieritas atau korelasi antar variabel independen diketahui melalui angka VIF yang berada disekitar angka 1 (satu) dan tidak lebih dari angka 10 (sepuluh) adalah sebagai berikut: Variabel Faktor kebudayaan $\left(\mathrm{X}_{1}\right)=1.009$, Variabel $\operatorname{Sosial}\left(\mathrm{X}_{2}\right)=1.007$, Variabel Faktor pribadi $\left(\mathrm{X}_{3}\right)=$ 1.005 , dan Variabel faktor psikologis $\left(\mathrm{X}_{4}\right)=1.002$. Sedangkan nilai tolerance untuk masing-masing variabel menunjukkan angka yang mendekati 1 , yaitu : Variabel Faktor kebudayaan $\left(\mathrm{X}_{1}\right)=0,991$, Variabel Sosial $\left(X_{2}\right)=0,993$, Variabel Faktor pribadi $\left(\mathrm{X}_{3}\right)=0,995$, dan Variabel faktor psikologis $\left(\mathrm{X}_{4}\right)=$ 0,994 .

Dengan demikian maka pada model regresi yang digunakan ini tidak ditemukan adanya gejala atau masalah multikolinearitas.

Berdasarkan hasil estimasi regresi pada tabel 2 memperlihatkan bahwa $F_{\text {hitung }}$ adalah 267,457, sedangkan nilai $\mathrm{F}_{\text {tabel }}$ dengan tingkat signifikan $5 \%$ df $=(40-4-1)$ adalah 3,81. Jika kedua angka tersebut dibandingkan nampaklah nyata bahwa $F_{\text {hitung }}$ lebih besar dari $F_{\text {tabel }}\left(F_{\text {hitung }}=267,457>F_{\text {tabel }}\right.$ $=3,81$. Ini berarti secara simultan/ keseluruhan Variabel Faktor kebudayaan $\left(\mathrm{X}_{1}\right)$, Variabel Sosial $\left(\mathrm{X}_{2}\right)$, dan Variabel Faktor Pribadi $\left(\mathrm{X}_{3}\right)$, dan Variabel Faktor Psikologis $\left(\mathrm{X}_{4}\right)$ berpengaruh signifikan terhadap pengambilan keputusan konsumen dalam melakukan kunjungan wisata (Y) pada taraf uji 5\%. Dari hasil Uji F di atas maka Hipotesis Nol (Ho) secara keseluruhan ditolak, sebaliknya Hipotesis Alternatif (Ha) secara keseluruhan diterima.

Berdasarkan hasil uji hipotesis di atas menunjukkan bahwa keputusan konsumen dalam berwisata (Y) di Kabupaten Hulu sungai Tengah secara simultan/ keseluruhan dapat diperkirakan melalui: Variabel Faktor kebudayaan $\left(\mathrm{X}_{1}\right)$, Variabel Sosial $\left(\mathrm{X}_{2}\right)$, dan Variabel Faktor Pribadi $\left(\mathrm{X}_{3}\right)$, dan Variabel Faktor Psikologis $\left(\mathrm{X}_{4}\right)$.

Berdasarkan estimasi regresi seperti yang dikemukakan pada tabel diketahui nilai $t_{\text {tabel }}$ untuk

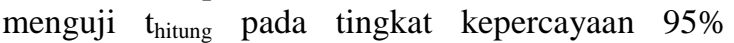
dengan taraf signifikansi 5\% dan derajat kebebasan (df) $:(n-k-1)=(40-4-1)=35$, maka $t_{\text {tabel }}=$ 1,684. Dengan berpedoman pada $t_{\text {tabel }}$ ini dapat dilaksanakan pengujian pada setiap variabel yang ada sebagai berikut :

a. Variabel Faktor kebudayaan $\left(\mathrm{X}_{1}\right)$, dari hasil uji Variabel menunjukkan $t_{\text {hitung }}=1.383<$ $\mathrm{t}_{\text {tabel }}=1,684$. Artinya Ho ditolak dan $\mathrm{Ha}$ diterima, dimana Variabel Faktor kebudayaan
$\left(\mathrm{X}_{1}\right)$ kurang berpengaruh signifikan secara statistik terhadap pengambilan keputusan konsumen dalam melakukan kunjungan wisata di Kabupaten Hulu Sungai Tengah (Y).

b. Variabel Faktor Sosial $\left(\mathrm{X}_{2}\right)$, dari hasil uji Variabel menunjukkan $\mathrm{t}_{\text {hitung }}=1.633<\mathrm{t}_{\text {tabel }}=$ 1,684. Artinya Ho ditolak dan Ha diterima, dimana Variabel Faktor Sosial $\left(\mathrm{X}_{2}\right)$ kurang berpengaruh signifikan secara statistik terhadap pengambilan keputusan konsumen dalam melakukan kunjungan wisata di Kabupaten Hulu Sungai Tengah (Y).

c. Variabel Faktor Pribadi $\left(\mathrm{X}_{3}\right)$, dari hasil uji Variabel menunjukkan $t_{\text {hitung }}=3.324>\mathrm{t}_{\text {tabel }}=$ 1,684. Artinya Ho diterima dan Ha ditolak, dimana Variabel Faktor Pribadi $\left(\mathrm{X}_{3}\right)$ berpengaruh signifikan secara statistik terhadap terhadap pengambilan keputusan konsumen dalam melakukan kunjungan wisata di Kabupaten Hulu Sungai Tengah (Y).

d. Variabel Faktor Psikologis $\left(\mathrm{X}_{4}\right)$, dari hasil uji Variabel menunjukkan $\mathrm{t}_{\text {hitung }}=5.428>\mathrm{t}_{\text {tabel }}=$ 1,684. Artinya Ho diterima dan Ha ditolak, dimana Variabel Faktor Pribadi $\left(\mathrm{X}_{3}\right)$ berpengaruh signifikan secara statistik terhadap terhadap pengambilan keputusan konsumen dalam melakukan kunjungan wisata di Kabupaten Hulu Sungai Tengah (Y).

Berdasarkan data uji t di atas jelaslah bahwa Variabel Faktor Psikologis $\left(\mathrm{X}_{1}\right)$ menunjukkan angka yang lebih besar dan paling berpengaruh signifikan secara statistik dari variabel lainnya sehingga dapat dikatakan bahwa variabel faktor psikologis merupakan variabel yang paling dominan secara statistik berpengaruh terhadap pengambilan keputusan konsumen dalam melakukan kunjungan wisata di Kabupaten Hulu Sungai Tengah (Y).

Berdasarkan hasil perhitungan diketahui bahwa koefisien determinasi disesuaikan (Adjusted R Square) sebesar 0,965 yang berarti bahwa variabel independen: Variabel Faktor kebudayaan $\left(\mathrm{X}_{1}\right)$, Variabel Sosial $\left(\mathrm{X}_{2}\right)$, dan Variabel Faktor Pribadi $\left(\mathrm{X}_{3}\right)$, dan Variabel Faktor Psikologis $\left(\mathrm{X}_{4}\right)$ mempunyai variansi kontribusi sebesar $96,5 \%$ terhadap variabel dependen : pengambilan keputusan konsumen dalam melakukan kunjungan wisata di Kabupaten Hulu Sungai Tengah (Y), sedangkan sisanya adalah 3,5\% diberikan oleh variabel-variabel lain yang tidak termasuk dalam penelitian ini.

\section{PENUTUP}

\section{Kesimpulan}

Keputusan konsumen dalam menentukan tujuan wisata yang akan di kunjungi berdasarkan hasil analisa pada tempat wisata yang ada di Kabupaten Hulun Sungai Tengah adalah lebih 
banyak didasarkan pada factor pribadi dimana banyak dipengaruhi oleh karakteristik psikologis seseorang yang berbeda dengan orang lain yang menyebabkan tanggapan yang relatif konsisten dan bertahan lama terhadap lingkungan, serta faktor psikologis yaitu bagian dari pengaruh lingkungan dimana ia tinggal dan hidup pada waktu sekarang tanpa mengabaikan pengaruh dimasa lampau atau antisipasinya pada waktu yang akan datang.

Perlu peran pemerintah dan swata dalam membina dan memberi akses yang lebih baik untuk pengembangan objek wisata dengan fasilitas yang memadai ,terutama dalam pembenahan fasilitas pariwisata sehingga masyarakat lebih mudah memanfaatkan untuk kegiatan wirausaha dan menciptakan peluang kerja baru dan bias lebih banyak menarik jumlah kunjungan wisata.

\section{DAFTAR PUSTAKA}

Arikunto, Suharsimi. 2006. Prosedur Penelitian Suatu Pendekatan Teori dan Praktik. Jakarta: Rineka Cipta.

Gitosudarmo. 2002. .Ekonomi Pembangunan Teori Masalah dan Kebijakan. Yogyakarta : UPP AMP YKPN.

Kotler P, 2010. Manajemen Pemasaran, Jakarta : PT. Macanan Jaya Cemerlang

Pramesti, Getut. 2008. Aplikasi SPSS dalam Penelitian. Jakarta : PT. Elex Media Komputindo

Sugiyono. 2002. Metode Penelitian Pendidikan Pendekatan Kuantitatif, Kualitatif dan $R$ \& D. Bandung: Alvabeta.

Soebagyo.2012. Strategi Pengembangan Pariwisata Di Indonesia.Jurnal Liquidity. (internet). (dikutip 15 September 2015). Jakarta : Fakultas Ekonomi Universitas Pancasila. Dapat diunduh dari :http://www.liquidity.stiead.ac.id/wpcontent/uploads/2012/10/8-_SoebagyoLiquidity-STIEAD.pdf.

Sudiarditha, I.K,. Suman, A, dan Kusnadi. 2008. Analisis Pengembangan Sektor Industri Pariwisata Terhadap Penyerapan Tenaga Kerja Dan Pendapatan Rumah Tangga Petani. Jurnal Wacana. 3(2) : 125-133

Sumarwan,Ujang. 2004. Perilaku Konsumen;teori dan Penerapannya Dalam Pemasaran. PT Ghalia Indonesia. Bogor

Utami, Indah Tri. 2013. Pengaruh Obyek Wisata Sendang Asri Waduk Gajah Mungkur Wonogiri terhadap Kondisi Sosial dan Ekonomi Masyarakat. Jurnal Sains Komunikasi dan Pengembangan Masyarakat
Widayati, Endang P, 2009. Faktor-faktor yang mempengaruhi Perilaku Konsumen Terhadap Keputusan Pembelian Minyak Goreng di Surabaya dengan Menggunakan Pendekatan Metode Struktural Equation Modelling (SEM). Jurnal Tekmapro. Vol.4 no 2. UPN "Veteran" Jawa Timur Surabaya.

\section{Profil penulis}

1. Gusti Marliani, SE., ME, Dosen Fakultas Ekonomi universitas Achmad Yani Banjarmasin.

Email : gustimarliani@uay.ac.id

2. Drs. Toto Sugiarto, MM, Dosen Fakultas Ekonomi universitas Achmad Yani Banjarmasin.

Email : totosugiarto@uay.ac.id 